\title{
Alcoholic Neuropathy
}

-Morphometric and Ultrastructual Study of Sural Nerve-

\author{
Satoru SHIRAISHI ${ }^{1}$, Naohide INOUE ${ }^{1}$, Yoshiyuki MURAI ${ }^{1}$ and Norio MATsuo ${ }^{2}$ \\ ${ }^{1}$ Department of Neurology, ${ }^{2}$ Second Department of Internal Medicine, School of Medicine, \\ University of Occupational and Environmental Health, Japan. Kitakyushu 807, Japan
}

\begin{abstract}
A 47-year-old female of alcoholic neuropathy was reported. She showed sensorimotor disturbance with glove and stocking type distribution. Electromyography demonstrated signs of denervation, and nerve conduction velocities were slightly decreased in the lower limbs. Quantitative histologic and ultrastructual studies were performed in the sural nerve biopsied. In the teased fiber analysis myelinated fibers showing axonal degeneration was observed in $36 \%$ and segmental demyelination in $12 \%$. Determinations of fiber densities revealed a remarkable decrease of the density of large myelinated fibers with normal density of small myelinated and unmyelinated fibers. The clinical, electrophysiological and histrometric findings of this case is similar to those of cases of beriberi neuropathy.
\end{abstract}

Key words: alcoholic neuropathy, large myelinated fiber loss, axonal degeneration.

(Received 14 August 1982)

\section{Introduction}

Alcoholic neuropathy is one of the most frequent neuropathies. However, there have been only few reports, studied by modern histological techniques, i. e. teased fiber analysis and morphometric evaluation of the nerves. The purpose of this paper is to elucidate the type of the involvement of the nerve in alcoholic intoxication applying modern techniques to the biopsied nerve, and to indicate a similarity of alcoholic neuropathy to beriberi neuropathy.

\section{Report of a Case}

A 47-year-old housewife had been drinking approximately 1.8 liters of "Sake" daily for about 6 months until October 12th 1981, when she noticed numbness, a tingling sensation and muscle weakness in the distal portion of the four extremities. "Sake" is made of rice, and has an alcoholic concent of 16-17 per cent. The symptoms rapidly progressed, and she became unable to walk in a few days. She was admitted to the University Hospital of Occupational and Environmental Health on December 28th 1981.

She was $150 \mathrm{~cm}$ in height and $47.5 \mathrm{~kg}$ in weight. No cardiac enlargement.was found. 
The liver was palpable 2 fingers' breadths below the costal margin. The spleen was not palpable. There was no ascites, and no edema was found in any portion of the body. Her systolic blood pressure was $120 \mathrm{mmHg}$ and diastolic $80 \mathrm{mmHg}$. She was alert and well oriented. Cranial nerves were intact. There was a moderate muscular weakness in the hands and fingers, and severe weakness in the lower legs and feet. Both knee and ankle jerks were absent bilaterally. Touch, pain, temperature and vibration senses were mildly impaired in the hands and moderately in the feet. No muscle tenderness was found. She was not able to walk.

\section{Laboratory data}

The blood chemistry showed mild liver dysfunction with a slight elevation of GOT

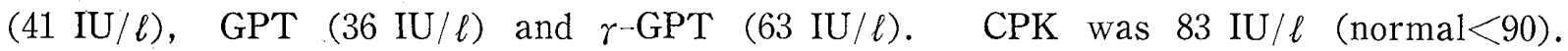
Vitamin $B_{1}$ in whole blood was $1.0 \mu \mathrm{g} / 100 \mathrm{ml}$ (normal range: $1.6-4.0 \mu \mathrm{g} / 100 \mathrm{ml}$ ), vitamin $B_{6}$ in plasma was $3.2 \mathrm{ng} / \mathrm{ml}(3.6-18.0 \mathrm{ng} / 100 \mathrm{ml})$, and vitamin $B_{12}$ in serum was $870 \mathrm{pg} /$ $100 \mathrm{ml}(300-1,000 \mathrm{pg} / \mathrm{ml})$. The other blood and urine analysis showed no abnormality.

Electromyography demonstrated abundant fibrillation potentials in the paralysed muscles, particularly in the leg muscles, and the number of motor unit potentials activated by voluntary contraction was markedly reduced in the muscles of the lower extremities. Motor conduction velocity in the right median nerve was $46.2 \mathrm{~m} / \mathrm{sec}$, and that in the right peroneal nerve was $38.3 \mathrm{~m} / \mathrm{sec}$, which was slightly decreased. No sensory potential was recorded when the sural nerve was stimulated.

\section{Clinical course}

With the administration of vitamin $\mathrm{B}_{1}, \mathrm{~B}_{6}, \mathrm{~B}_{12}$, diet therapy and abstinence from "Sake", the sensory and motor disturbances and liver dysfunction gradually improved, and she was able to walk without using any walking sticks two months after the onset of the treatment. Fascicular biopsy of the sural nerve was performed 4 weeks after the onset of the neurological symptoms.

\section{Histological Studies}

The sural nerve biopsied at the ankle level was fixed with $3 \%$ glutaraldehyde in $0.1 \mathrm{M}$ cacodylate buffer ( $\mathrm{pH} \mathrm{7.40)}$ for 2 hours. Then the tissue was washed, and divided into two portions, one for epoxy sections and the other for teased fiber preparations. The former was postfixed in $2 \%$ osmium tetroxide for 2 hours, dehydrated, and embedded into epoxy. Thick epoxy sections with a thickness of $1.5 \mu \mathrm{m}$ were stained with toluidine blue, and observed using a light microscopy. Thin slices were stained with uranyl acetate and lead citrate, and examined with an electron microscope. Using latter preparations, the condition of each teased fiber was classified according to Dyck's method (1975). Photographic enlargements $(\times 1,000)$ of transverse epoxy sections were used to obtain the 
density (the number per square millimeter of fascicular area) of large (diameter $>5 \mu \mathrm{m}$ ) and small (diameter $\leqq 5 \mu \mathrm{m}$ ) and total (both large and small) myelinated fibers and their size frequency distribution. In order to obtain the density and size frequency distribution of unmyelinated fibers, electronmicrographs $(\times 7,500)$ were used.

\section{Teased fiber study}

The frequency of each condition of teased fibers of the sural nerve is showed in

Table 1. Frequency (\%) of teased fiber conditions

\begin{tabular}{ccccccc} 
& \multicolumn{5}{c}{ Condition } \\
Sural nerve & A & B & C & D & E & F \\
\hline Control & 98 & 0 & 0 & 0 & 1 & 1 \\
Patient & 51 & 1 & 8 & 1 & 36 & 3 \\
\hline
\end{tabular}

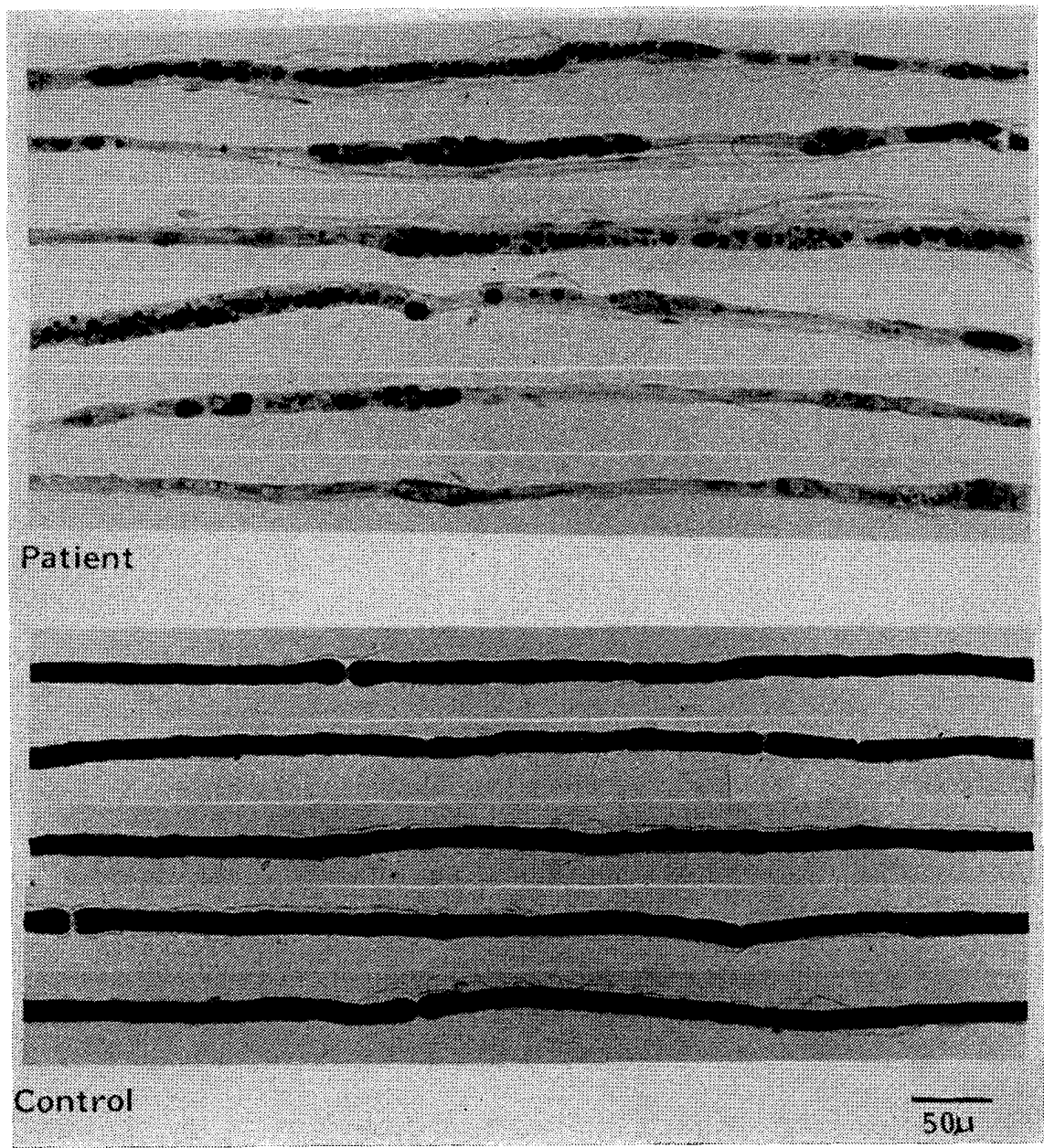

Fig. 1. Teased fiber preparation. Consecutive portions of one myelinated fiber (upper) showing linear rows of myelin ovoids. 
Table 2. Numbers (No. $/ \mathrm{mm}^{2}$ ) of nerve fibers

\begin{tabular}{ccccc} 
& \multicolumn{3}{c}{ Myelinated fibers } & Unmyelinated \\
\cline { 2 - 4 } Sural nerve & Total & Large & Small & fibers \\
\hline Control & 8340 & 4149 & 4191 & 24420 \\
Patient & 4320 & 562 & 3758 & 21000 \\
\hline
\end{tabular}

Large fibers

Diameter $>5 \mu \mathrm{m}$

Small fibers

Diameter $\leqq 5 \mu \mathrm{m}$

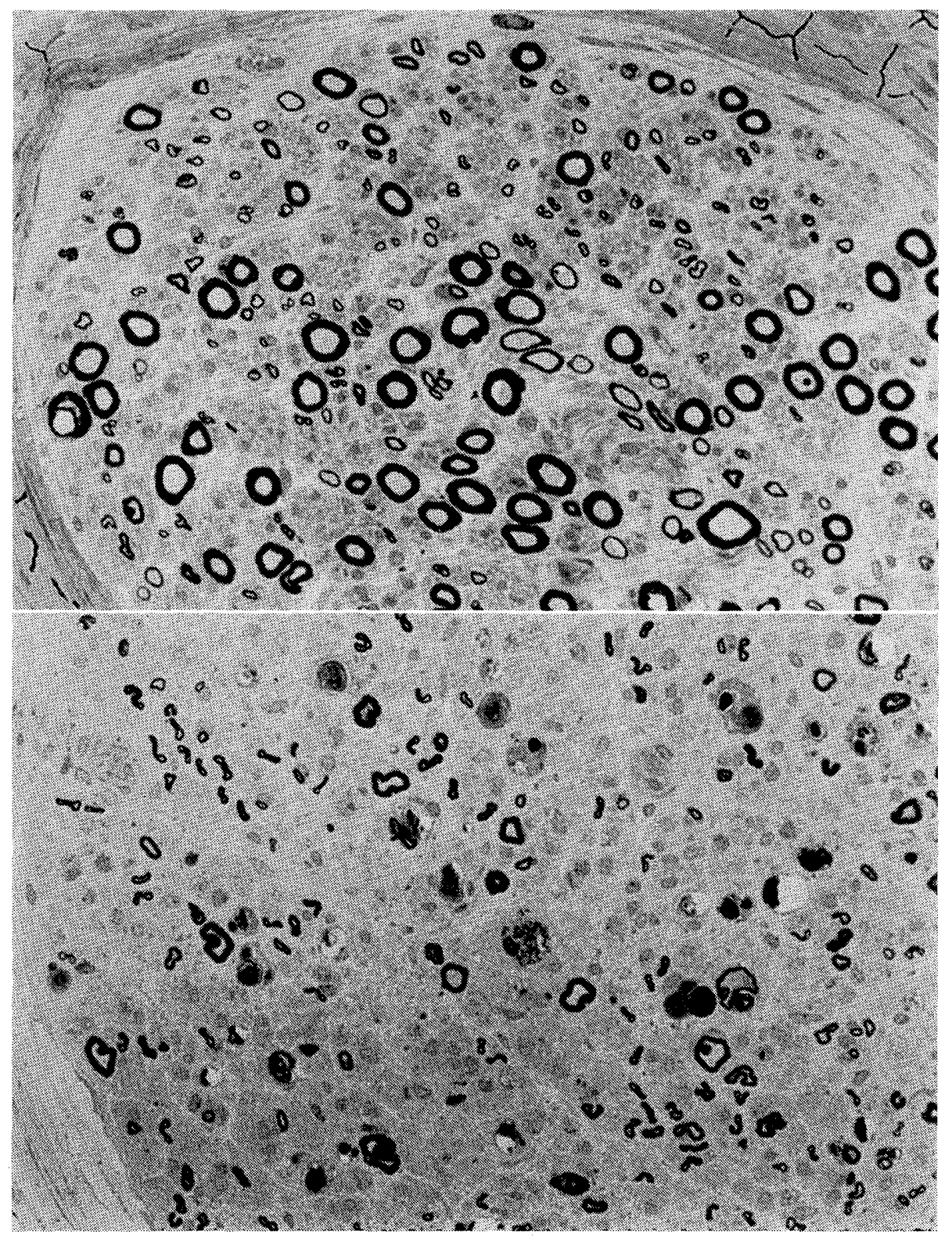

Fig. 2. Transverse section of sural nerve control (upper) and our case of alcoholic neuropathy (lower). Note myelin ovoids, thin myelin sheath relative to the diameter and decrease of the density of large myelinated fiber. Toluidine blue staining $(\times 400)$ 
Table 1. The frequency of abnormalities of teased fibers was markedly higher than that in control. The frequency of condition $\mathrm{E}$, in which myelinated fiber shows linear rows of myelin ovoids and balls (Fig. 1), was 36\%. That of condition C, D, F, in which myelinated fiber shows segmental demyelination, was $12 \%$. The main form of fiber abnormality was axonal degeneration.

\section{Light microscopy}

The transverse epoxy section viewed under a light microscopy also showed abnormal findings. Myelin ovoids were frequently seen. Fibers with abnormally thin myelin sheath relative to the diameter and demyelinated axons were occasionally seen (Fig. 2).

The density of total, large and small myelinated fibers is shown in Fig. 3, Table 2. The density of total and large myelinated fibers was significantly decreased in our case
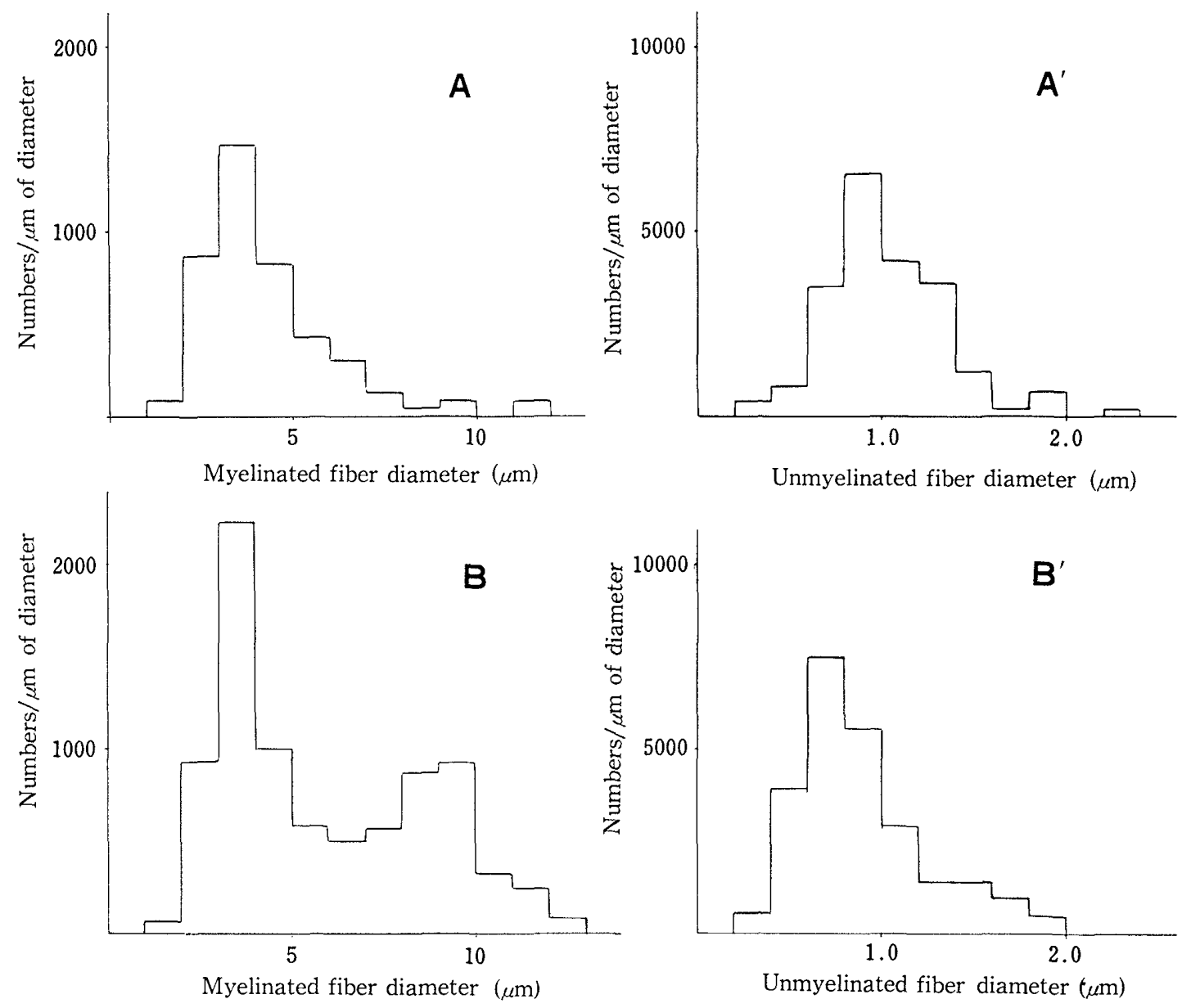

Fig. 3. The diameter histograms of myelinated and unmyelinated fibers per square millimeter of fascicular area of sural nerve in control (lower B, B') and patient (upper $\mathrm{A}, \mathrm{A}^{\prime}$ ). Note decrease in number of large myelinated fibers with the preservation of numbers of small myelinated fibers (A) and unmyelinated fibers $\left(\mathrm{A}^{\prime}\right)$. 


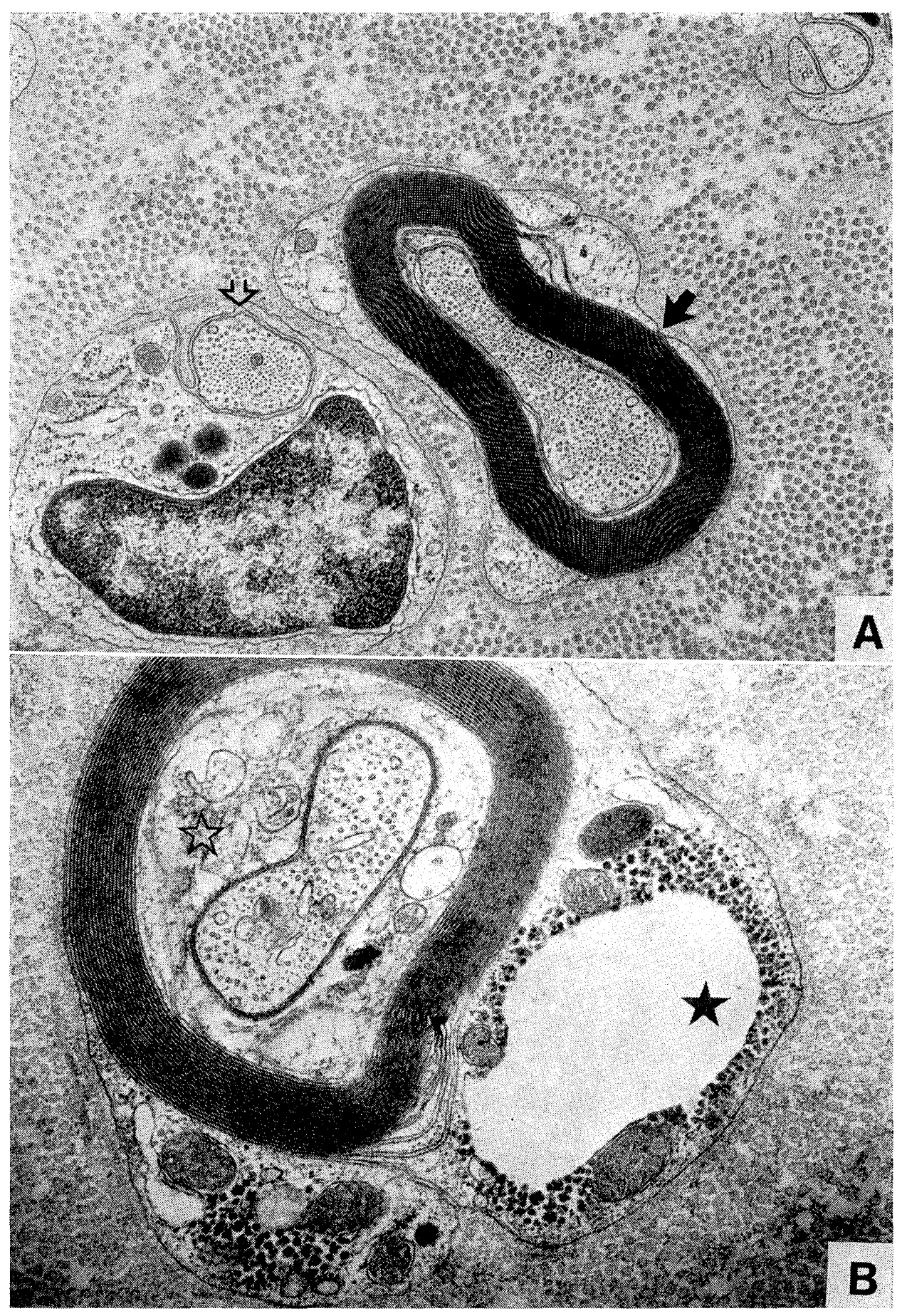

Fig. 4-A. Electron micrograph (E. M.) of the sural nerve in transverse section. One myelinated fiber $(\rightarrow)$ and one unmyelinated fiber $(\Rightarrow)$ : almost normal structure. $(\times 16,000)$

4-B. E. M. section. One myelinated fiber had numerous increases of organells in inner mesoaxon $(\zeta)$ and a huge vacuole was seen in the Schwann cell cytoplasm $(\star) .(\times 10,000)$ 


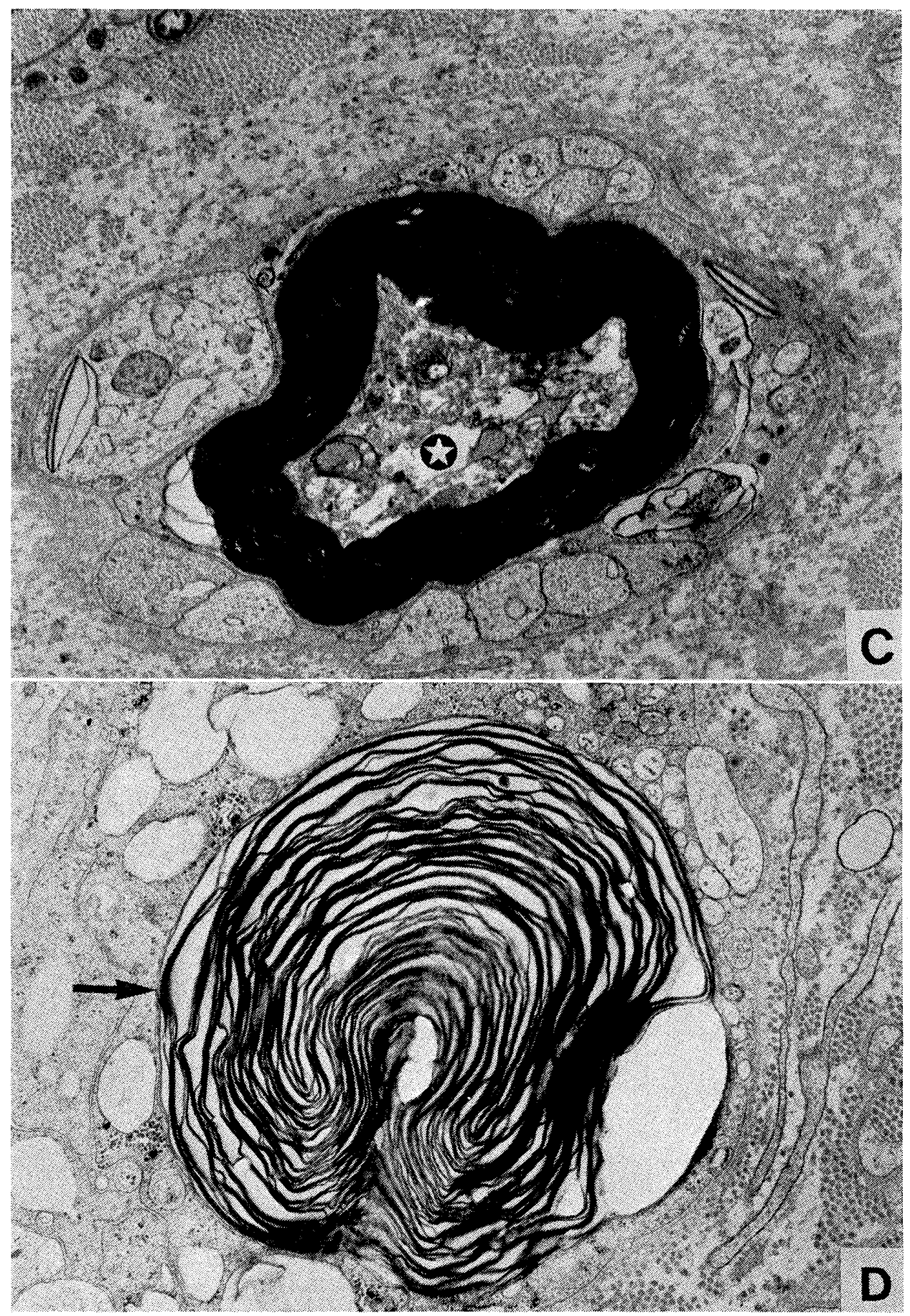

4-C. E. M. section. Severe degenerative finding was seen with granular disintegration of axoplasmic organells $(\times 10,000)$

4-D. E. M. section. Schwann cell filled with membranous structure and debris of myelin theath $\rightarrow) .(\times 10,000)$ 
compared with control. On the other hand, the density of small myelinated fibers was similar in our case and control.

\section{Electron microscopy}

Electron microscopic findings showed various stages of demyelinated axons. One myelinated fiber showed almost normal myelin sheath and intraaxonal organs and the other Schwann cell nucleus and one unmyelinated fiber had also almost normal intraaxonal organells (Fig. 4-A). Another myelinated fiber showed moderately abnormal findings.

The organells of inner mesoaxon was increased and a huge vacuole was seen in the Schwann cell cytoplasm (Fig. 4-B).

Severe degenerative findings were seen with granular disintegration of axoplasmic organells (Fig. 4-C). In another part of the nerve we could see debris of myelin sheath filled with membranous structure in Schwann cell cytoplasm (Fig. 4-D).

The unmyelinated fiver density was similar in our case and control as shown Table 2, Fig. 3.

\section{Discussion}

The patient presented here was a middle aged housewife who subsequently developed symmetrical sensorimotor neuropathy in the four extremities with mild liver dysfunction. Although, alcoholic neuropathy with typical sensorimotor disturbances is a relatively rare disease in Japan, if we examined carefully and employed laboratory techniques there would be many more patients with mild signs or subclinical cases. In 1953, Victor and Adams found evidences of polyneuropathy in about $8 \%$ of hospitalized alcoholics. However, recent studies performed using modern electrodiagnostic techniques have indicated greater prevalence of alcoholic polyneuropathy. Worden (1974), reported 70\% neuropathic patients among 150 alcoholics, and Lefebvre-D'Amour et al. (1976) found subclinical evidence of peripheral nerve dysfunction in 28 cases of 30 randomly selected alcoholics.

Although there have been some histological studies of alcoholic neuropathy, only few studies have been performed employing the modern histological techniques. In this report, teased fiber analysis demonstrated $36 \%$ of axonal degeneration and $12 \%$ of segmental demyelination which indicated axonal degeneration was predominant. Electron microscopic findings also showed various changes of axonal degenerations. Morphometrical fiber density study showed remarkable reduction of the large myelinated fibers without any significant changes in the number of small myelinated and unmyelinated fibers.

On the pathogenesis of alcoholic neuropathy, there have been two main theories; one stressed direct toxic effect of alcohol (Behse \& Buchthal, 1977), and the other nutritional deficiency (Mayer, 1966). According to Mayer, about $60-80 \%$ of cases of alcoholic neuropathy had completely recovered with abstinence and adequate nutrition. In our case, whole blood vitamin $\mathrm{B}_{1}$ and plasma vitamin $\mathrm{B}_{6}$ levels were decreased, and the 
sensorimotor neuropathy gradually improved in two months with the administration of vitamin $\mathrm{B}_{1}, \mathrm{~B}_{6}, \mathrm{~B}_{12}$ and diet therapy, which indicated that the inadequate nutritional state was the cause of the neuropathy.

Because the cause of our case of alcoholic neuropathy was considered to be nutritional, especially vitamin B group deficiency, we compared our case with beriberi neuropathy (Takahashi \& Nadamura, 1976; Ohnishi et al., 1980).

Both diseases showed similar sensorimotor neuropathy, which responded to vitamin B group and diet therapy. Electromyography demonstrated signs of denervation, and nerve conduction velocities were within normal limits or slightly decreased in both conditions, which was compatible with axonal neuropathy.

Similarities were also found in the histological studies; Teased fiber analysis and electron microscopic studies indicated that the axonal degeneration is the main type of those two neuropathies and morphometric fiber density study showed a remarkable reduction of large myelinated fibers with normal density of small myelinated and unmyelinated fibers.

Recently, Blass \& Gibson (1977) reported that alcohol intake produced vitamin $\mathrm{B}_{1}$ deficiency in humans. This Blass' study and the above mentioned similarity in clinical, electrophysiological and histological evidence were strongly suggestive of a similar mechanism in alcoholic and beriberi neuropathies.

\section{Acknowledgement}

We would like to thank Professor S. Fujimoto, Associate Professor K. Yamamoto, Instructor I. Hayabuchi of the Department of Anatomy, Miss R. Kaku, Miss T. Kitagawa of the Department of Neurology, University of Occupational and Environmental Health, and Assistant Professor A. Ohnishi of the Department of Neuropathology, Kyushu University.

\section{References}

Behse, F. \& Buchthal, F. (1977): Alcoholic neuropathy: Clinical, electrophysiological and biopsy findings. Ann. Neurol., 2: 95-110.

Blass, J. P. \& Gibson, G. E. (1977): Abnormality of a thiamine-requiring enzyme in patients with Wernicke-Korsakoff syndrome. N. Engl. J. Med., 297: 1367-1370.

Dyck, P. J. (1975): Pathological alterations of the peripheral nervous systems of man. In: Peripheral Neuropathy. (P. J. Dyck, P. K. Thomas \& E. H. Lambert, ed.), W. B. Saunders, Philadelphia. pp. 253-263.

Lefebvre-D'Amour, M., Shahani, B., Young, R. et al. (1976): Importance of studying sural conduction and late responses in the evaluation of alcoholic subjects. Neurology, 26:368.

Mayer, R. F. (1966): Peripheral nerve conduction in alcoholics: Studies of the effects of acute and chronic intoxication. Psychosom. Med., 28: 475-483.

Ohnishi, A., Tsuji, S., Igisu, H. et al. (1980): Beriberi neuropathy morphometric study of sural nerve. J. Neurol. Sci., 45: 177-190.

Takahashi, K. \& Nadamura, H. (1976): Axonal degeneration in beriberi neuropathy. Arch. Neurol, 
33: $836-841$

Tredici, G. \& Minazzi, M. (1975): Alcoholic neuropathy on electron-microscopic study. J. Neurol. Sci. , 25: 333-346.

Victor, M. \& Adams, R. D. (1953): Effect of alcohol on the nervous system. Proc. Assoc. Res. New Ment. Dis., 32: 526-573.

Walsh, J. C. \& McLeod, J. G. (1970): Alcoholic neuropathy an electrophysiological and histological study. J. Neurol. Sci., 10: 457-469.

Worden, R.E. (1974): Alcoholism: Electrodiagnostic studies. Arch. Phys. Med. Rehabil., $55: 595$.

アルコール性のニューロパチー

一腓腹神経の組織定量的おょび電顕的観察—

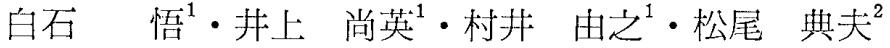

1産業医科大学神経内科学教室 2 产業医科大学第 2 内科学教室

要旨：症例は 47 歳, 女性。アルコール性ニューロパチーにより手袋靴下状の運動感覚障害を星 した。笳笔図では脱神経所見を，神経伝導检査では下肢で軽度の伝導速度遅延を認めた。 腓腹神経による組織定量的な解析と電子顕微鏡的钼察を行った。末梢神経ときほぐし法で は軸索変性所見を $36 \%$ 亿，節性脱舭所見を $12 \%$ 亿琹めた。横断標本による神経線維密度 の観察では大径有骪線維の脱落が著明であったが，小径有髄線維無髄線維密度はコント

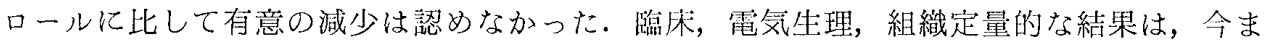
で報告されている脚気ニューロパチーときわめて類似していた。

J. UOEH（産業医大誌），4（4)：495-504（1982） 